COMMENT

Received 26 Jan 2016 | Accepted 29 Mar 2016 | Published 26 Apr 2016

DOI: 10.1057/palcomms.2016.12

\title{
Critical gender studies and international development studies: interdisciplinarity, intellectual agility and inclusion
}

Yvonne Underhill-Sem ${ }^{1}$

\begin{abstract}
Critical gender studies and international development studies are both interdisciplinary, but intellectual agility can ensure they are inclusive sites of knowledge production. To develop intellectual agility, which underpins progressive interdisciplinarity, students must paradoxically venture into more closely defined disciplinary traditions in the social sciences, the humanities and the sciences. Intellectual agility begins by being fully cognizant of epistemological and theoretical framings in substantive debates, such as, for instance, the perpetuation of violence against women or the entrenchment of poverty. I argue that by explicitly tethering ideas to disciplinary traditions, interdisciplinary research and teaching can more successfully address pressing international development concerns in an inclusive manner. International development studies can easily be seen as utilitarian and instrumental just as critical gender studies can easily be seen as impractical and vague. Here, I show how I have worked critical gender studies into international development studies so that students can develop intellectual agility. Underpinning this is the call for progressive interdisciplinary research and teaching delinked from the defensive claims of long-standing scholarly traditions or the aspirational ambitions of newly cast bodies of knowledge. This article is published as part of a thematic collection dedicated to multi- and interdisciplinary perspectives on gender studies.
\end{abstract}

\footnotetext{
${ }^{1}$ Development Studies, University of Auckland, Auckland, New Zealand
} 
S ow (2002) in her remarkable piece on President Leopold Sedar Senghor, who in 1960 became the first president of Senegal, succinctly articulates the tensions of post-colonial African feminism. She celebrates his success as a poet in scripting the beautiful poem Black Woman. At the same time, she notes that he was ushering his country into the complexities of a postcolonial world. Sow writes that even in his success, he also deeply disappoints. Her article elegantly shows how a critical feminist scholar navigates disciplinary knowledge in the humanities and social sciences to powerfully depict the gendered context and processes of a post-colonial moment that ultimately contributed to entrenched gender inequality in Senegal. Although written in the colonial language of French, the message in the English version that my students read is clear: to address the deep structures of gender oppression, it is important to understand gender relations, structural inequality and patriarchal privilege. And to do this one must learn to be intellectual agile-a feature I would argue is fundamental to wide interdisciplinary studies (Kelly, 1996).

This text welcomes my students to an introductory graduate course in a small postgraduate programme, simply titled "Gender and Development", and signals the need for interdisciplinarity and agile thinking. Throughout the course, students read philosophy, anthropology, sociology, politics and economics, and my own discipline of geography. Part way through the course, students raise routine concerns. "When are we going to learn how to do gender analysis?", or "I have been doing gender analysis in my organization for many years and I am still waiting to see how this is relevant?". However, after 12 weeks of reading and discussing material from different disciplines, students start developing the intellectual agility needed to begin to do interdisciplinary research in international development studies with a critical gender lens. This is research that tackles problems such as engrained poverty and gender-based violence, both of which require multi-dimensional responses because of entrenched power dynamics that perpetuate and sustain inequalities. Importantly in international development studies, there is a strong imperative to suggest "interventions"-polices or programmes that go some way to alleviate problems. Sometime these are pragmatic and instrumental; sometimes they offer nuanced guidance for cognitive transformation. Dealing with a range of possible responses is a common challenge both in international development studies and critical gender studies, and this challenge is why students need to become agile intellectuals. They need to be able to read across disciplinary boundaries, integrate their learnings and become strategic in their proposed solutions. These are key features in the burgeoning area of interdisciplinary studies in all its different forms (Klein, 2009; Repko et al., 2014).

Moreover, students begin to learn that to be "change agents" also requires intellectual agility (Kesby, 2005). While more time in class would fully ground this agility into practice, being introduced to this agility is undoubtedly the beginning of critical international development studies. This agility allows students to deconstruct what seems evident before reconstructing in ways that makes possible diverse options. Critical gender studies are central to this process of developing agile thinking. It is another interdisciplinary area of study, but in contrast to the instrumentalism that dominates international development studies the imperative is criticality as intellectual and social practice (Danvers, 2015). As a body of knowledge, critical gender studies "speaks truth to power" in its many dimensions (Woodward and Woodward, 2015) that allows for wide-ranging challenges such as to neoclassical economics, which continues to dominate mainstream international development policies and practices (Mohanty, 2003). This is also evident in pointed critiques of the gender smart economics that are promoted by the World Bank (Chant and Sweetman, 2012).

Critical gender thinking in international development studies can emerge in many and various ways. Embodied experiences, like brutal rapes (Lodhia, 2015), can reveal the complexities of inequality and injustice in widespread public mobilizations. Solidarity politics, like support for the Chibok school girls abducted in Nigeria, can throw into sharp relief post-colonial politics of differently situated and distant support (Khoja-Moolji, 2015). Affective technologies (Schwittay and Boocock, 2015) can present imperatives to engage with the business of development as a stranger. Notwithstanding the long-standing antitheory critique of international development studies, I argue that international development studies programmes that engage with critical gender thinking can train agile thinkers. This would mean presenting paradoxical situations, inviting clarity on one's positionality and recognizing partiality in all responses. And, this is vital for rethinking international development policies and practices in the increasingly paradoxical and unjust post-colonial world, where theory and ethics must make explicit how practices of international development are framed.

\section{Critical international development studies: gender and development}

International development studies programmes and courses have expanded enormously in over the last decade and especially those focused on gender and development. Targeted degrees are offered in a range of related fields such as gender violence and conflict, gender analysis in international development and gender, development and globalization. Fracturing a broad area of study into specified degrees enhances technical expertise in gender and development at the same time as it contributes to the expansion of postgraduate education in modern "neoliberalizing" universities (Shore and Davidson, 2014). Further, courses are shared online for wider consumption. There is a democratic value in this sharing; however, the irreplaceable value of face-to-face engagement is overlooked. Given that mainstream international development policy-making and practice often occurs at vast social, economic, political and cultural distances, face-to-face engagement is critical for its effect on progressive knowledge production.

In this context, the postgraduate classroom that includes students who are diversely situated with respect to language, race, sexual orientation, religion, class and gender can be seen as a special space for learning about international development practice. Students can engage face-to-face with each other and this allows for the relational and dynamic dimensions of personal ethical engagement to be experienced and conceptualized. Observing this engagement lead me to think more carefully about the notion and effect of intellectual agility as a process. Importantly, this reflection highlighted the different kinds of interdisciplinarity produced by international development studies (the study of the processes of change that lead to global poverty, inequality and the accompanying social, cultural and political transformations) and critical gender studies (the study of gender and sexuality and how it intersects with other social identities).

Partnerships have long been critically scrutinized in international development ever since they were seen as addressing the problems of participation and implementation (Pattberg and Widerberg, 2014). At the same time there is a steady flow of analysis that continually redeems the concept of partnership based on the particularities of successful partnerships (for example, Impey and Overton, 2014). In international development practice, partnerships just do not seem to go away. Part of 
the reason for this persistence, I argue, is the imperative of the relational dimension of "partnering" between "actors"-the affects of engagement. These include emotions of compassion, anger, guilt and determination.

To fully understand the relational dimension of partnerships in international development, we need to understand the ongoing process by which "new" actors and new subjectivities in development come to be (Underhill-Sem, 2012). But it also requires understanding the paradox of partnering in development that allows for both being "part of" and being "apart from" (Noxolo et al., 2012) -in this case, a postgraduate class on gender and development. This post-colonial reading of the practice of partnering is particularly pertinent to the notion of inclusive international development. "Inclusion" has become a notable emerging qualifier, somewhat like "social" capital, at a time when the United Nations is launching its new international development agenda with 17 Sustainable Development Goals. International development "actors" are important in this new agenda as material embodied persona through which they must moderate themselves and their intersecting identities. However, the subject positions in this terrain are constituted by discourses and practices of international development, which create subtle ambiguities that are intimately entangled in international development processes (Underhill-Sem, 2012). As "new" subjectivities form sense-making groups, or collectivities, these simultaneously create both hegemonic and progressive economic and political projects (Ibid.). It is therefore an ongoing process of working out the relational, affective and dynamic dimensions of partnering with new subjectivities that supports the notion of "partnerships" to flourish despite the constant criticism of them as a mode of international development.

Fortunately, my classes in gender and development have long been constituted by a very diverse group of students and have had to work through similar kinds of relational, affective and dynamic dimensions of partnering. My last class of 14 students included a woman and a man from Bangladesh, a woman from each of the following countries-Cambodia, China, Jamaica, Kyrgyzstan, Philippines and Tonga-and five women from New Zealand. We also had a man from Colombia. Their disciplinary backgrounds included sociology, politics, anthropology, social work, psychology, economics and geography. They had work experience in large NGOs, small NGOs, and a range of government departments and their previous degrees ranged from international relations to social welfare. Their ethnic, social and cultural backgrounds varied as did their family situations, religious background and life experiences. They were keen students but also committed to working in the international development field and amenable to becoming intellectually agile.

One way to develop students' intellectual agility while making the links between working in diverse groups, the practice of partnering and international development was to begin with a close reading of interdisciplinary scholarship, such as that by Sow. Unsurprisingly responses to reading Sow were diverse. Diverse response became even more apparent in a discussion about body politics initiated by a reading of disciplinary discrete scholarship (see also Lacey and Smits, 2015). Each person considered their understanding of transgender identities and the expressions of this in daily public life. Collectively there was agreement with a rights-based argument of inclusion. However, there was expressed personal discomfort from some students about sharing a public bathroom with someone who does not "belong" to that gendered space. This took us back to considering the nature of sex/gender systems (Rubin, 1975). In particular, we discussed how these systems move across space and through different cultural and religious codes of conducts. The challenge for many students was to consider progressive codes intellectually and in different places.
In the course of 2 hours, our discussion ranged from a parochial debate on the practice and challenges of rights-based policy in a New Zealand university, to the careful consideration of transgender identities and experiences, to the discomfort of personally confronting one's own practice and preference, and back to the intellectual underpinnings of how to think through the tensions of converging or diverging sentiments around a critical gender issue in international development.

Inclusive research, policy and practice require the agile intellectual engagements with paradoxical issues (Underhill-Sem et al., 2014) and this requires partnering. This practice can be developed in university courses but I argue not without theory and not without a particular kind of ethics. Interdisciplinarity in critical gender studies heightens this kind of scholarly engagement because it requires a constant reframing of the issue. In a post-colonial development world where the layers of complicity are complex and multiple, this is especially pertinent. While the notion of framing requires attention to exclusionary processes (Fraser, 2009), it is central to the intellectual partnering of critical gender studies with international development studies.

Rubin's (1975) thinking on sex/gender systems is a critical part of the course. While some students struggle with the wide scope of work that she engages with, it is useful for two reasons. First, it disturbs a key notion in gender and international development thinking and advocacy-namely, patriarchy. It does this by critically analysing the Marxist canon from which emerge the concepts of patriarchy, "oppression" and "submission" that have long-structured advocacy around gender inequality. However, this is an intellectually disruptive action not an outright dismissive one because these concepts have relevance in some places and times. For me, notions of industrial capitalism and especially women's labour as a commodity did not sit comfortably with my intellectual sense-making and lived experience of gender inequality in the Pacific (see Josephides, 1985). However, recent engagements with capitalism in the Pacific resonate more tunefully (McCormack and Barclay, 2013), although Hirsch (2014: 78) cogently argues that "there are limitations to all analytical ideas" and even "Foucault among the Melanesianists will surely continue to provoke debate".

The second reason Rubin is useful is that it offers an alternative conceptual framework that requires close consideration of historical and cultural contexts. Increasingly the historical dimension of international development is fading from contemporary accounts of global inequality and injustice. At the same time new cultural complexes are emerging. Both have critical implications for women. Rubin's feminist scholarly text combines a number of analytical ideas from anthropology, politics, philosophy and psychology that invite a critical interdisciplinary analytic. It requires readers to engage, disengage and then regroup their ideas around an emerging argument. It is a less ideologically disputable framework than, for instance, a patriarchy-focused one, or a human capital one. This provides students with a theoretical platform to rest on lightly as they learn that theoretical discomfort is part of the interdisciplinarity of both critical gender studies and international development studies.

A shared feminist ethics of practice is also an important imperative in critical gender studies and international development studies. The key principles of feminist ethics of practice are mutual respect, recognition of differences, commitment to nonhierarchical modes of organization, an obligation to care and intergenerational transfers of knowledge and power (Cave et al., 2012). Teaching as a space of ethical decision-making - as a social practice-must also embrace these principles and this space is possible with care ethics inspired by intersectionality (Hankivsky, 2014). This practice is an important component of my seminar teaching. Rarely do I know much about my students when they 
arrive in my class so work is needed to make the space safe for everyone. This commitment to care in the classroom has demonstrable effects in the challenging but productive discussions that emerge in the course of the semester.

This is also what makes the seminar room an interesting site for learning about international development practice. It is routine practice in the international development sector to engage with many and diverse peoples, using different languages and with everyone having varying concerns and priorities. To be productive in such spaces, international development practitioners need to deliver a range of outcomes, some more and some less explicit. Students in a postgraduate course are not expected to actually deliver such outcomes; however, their experience in such settings can go beyond internalizing the sensibilities promoted by seminar discussions.

The degree to which the contributions that students in my classes make towards progressive social change rests heavily on their ability to be intellectually agile, explicitly inclusive and personally tolerant. As an area of research and practice, international development studies easily becomes complicit with the machinery that contributed to the emergence of "development" in the first place (Escobar, 2012). Salaries, research funding and other financial inducements combine with the affective power of helping less-privileged others to confuse critical community collaborations (Cave et al., 2012) from which the scholarly study of international development must be based. Fortunately, increasingly reflective and critical feminist analysis is keeping open the space for such a work (see, for example, Nagar, 2014). These innovative spaces are not without tension. My own experience of discomfort is due to the interdisciplinary nature of international development studies, albeit in an instrumental form, and gender studies, specifically in its critical form (Huutoniemi et al., 2010). Both have, at times, been untenable, argumentative and compromising. One untenable situation was when the uneven depth of conceptual engagement in critical feminist scholarship in a research group led to the withdrawal of some contributions. One argumentative situation arose because the attribution of ideas was contested between those who make their living as writers and those who do not so that in the end authorship was acronymized. One compromised situation was where despite a commitment to a collective feminist hybrid writing style, the emotive expression when describing empirical material was constantly kerbed (Underhill-Sem et al., 2014).

I have found a shared feminist politics useful in overcoming disciplinary tensions that arise from efforts to work in an interdisciplinary fashion with colleagues who have backgrounds in sociology, anthropology, history, politics, philosophy, planning and operations research, and my own subject area of geography. Working with colleagues from the physical sciences has been notably less successful, despite advances in this area (see Schiebinger and Schraudner, 2011) and even though the compounding inequalities of gender are becoming more apparent in climate change science in the Pacific. Widespread scholarly grounding presents the possibility for intellectual agility in the interdisciplinary fields of critical gender studies and international development studies. This can be further nuanced by the lived experience or acknowledged heritage in the places under scrutiny. This invites consideration of another area of progressive or even radical interdisciplinarity (Holm et al., 2013) - one that deals with indigenous worldviews and non-human agency. But that is another paper.

\section{References}

Cave J, Johnston L, Morrison C and Underhill-Sem Y (2012) Communityuniversity collaborations: Creating hybrid research and collective identities. Kotuitui: New Zealand Journal of Social Sciences Online; 7 (1): 37-50.
Chant S and Sweetman C (2012) Fixing women or fixing the world? 'Smart economics', efficiency approaches, and gender equality in development. Gender \& Development; 20 (3): 517-529.

Danvers EC (2015) Criticality's affective entanglements: Rethinking emotion and critical thinking in higher education. Gender and Education; 28 (2): 1-16.

Escobar A (2012) Encountering Development: The Making and Unmaking of the Third World. Princeton University Press: Princeton, NJ.

Fraser N (2009) Scales of Justice: Reimagining Political Space in a Globalizing World. Columbia University Press: New York.

Hankivsky O (2014) Rethinking care ethics: On the promise and potential of an intersectional analysis. American Political Science Review; 108 (2): 252-264.

Hirsch E (2014) Foucault among the Melanesianists. Oceania; 84 (1): 69-79.

Holm P et al (2013) Collaboration between the natural, social and human sciences in global change research. Environmental Science \& Policy; 28 (1): 25-35.

Huutoniemi K, Klein JT, Bruun H and Hukkinen J (2010) Analyzing interdisciplinarity: Typology and indicators. Research Policy; 39 (1): 79-88.

Impey K and Overton J (2014) Developing partnerships: The assertion of local control of international development volunteers in South Africa. Community Development Journal; 49 (1): 111-128.

Josephides L (1985) The Production of Inequality: Gender and Exchange among the Kewa. Tavistock: London.

Kelly JS (1996) Wide and narrow interdisciplinarity. The Journal of General Education; 45 (2): 95-113.

Kesby M (2005) Retheorising empowerment-through-participation as a performance in space: Beyond the tyranny to transformation. Signs; 30 (4): 2038-2065.

Khoja-Moolji S (2015) Becoming an "intimate publics": Exploring the affective intensities of hashtag feminism. Feminist Media Studies; 15 (2): 347-350.

Klein JT (2009) Creating Interdisciplinary Campus Cultures: A Model for Strength and Sustainability. John Wiley \& Sons: San Francisco.

Lacey A and Smits K (2015) Reflections from the field: Teaching feminism/teaching as a feminist in politics departments. Women's Studies Journal; 29 (1): 56.

Lodhia S (2015) From "living corpse" to India's daughter: Exploring the social, political and legal landscape of the 2012 Delhi gang rape. Women's Studies International Forum; 50 (1): 89-101.

McCormack F and Barclay K (2013) Insights on capitalism from Oceania. Research in Economic Anthropology; 33 (1): 1-27.

Mohanty CT (2003) "Under western eyes" revisited: Feminist solidarity through anticapitalist struggles. Signs; 28 (2): 499-535.

Nagar R (2014) Muddying the Waters: Coauthoring Feminisms across Scholarship and Activism. University of Illinois Press: Urbana, Chicago and Springfield.

Noxolo P, Raghuram P and Madge C (2012) Unsettling responsibility: Postcolonial interventions. Transactions of the Institute of British Geographers; 37 (3): 418-429.

Pattberg P and Widerberg O (2014) Transnational multi-stakeholder partnerships for sustainable development: Building blocks for success, Available at SSRN 2480302, Institute for Environmental Studies, VU University of Amsterdam, De Boelelaan.

Repko AF, Szostak R and Buchberger MP (2014) Introduction to Interdisciplinary Studies. Sage Publications: Thousand Oaks.

Rubin G (1975) The traffic in women: Notes on the political economy of sex. Toward an Anthropology of Women; 157-210.

Schiebinger L and Schraudner M (2011) Interdisciplinary approaches to achieving gendered innovations in science, medicine, and engineering. Interdisciplinary Science Reviews; 36 (2): 154-167.

Schwittay A and Boocock K (2015) Experiential and empathetic engagements with global poverty: 'Live below the line so that others can rise above it'. Third World Quarterly; 36 (2): 291-305.

Shore CN and Davidson M (2014) Beyond collusion and resistance: Academicmanagement relations within the neoliberal university. Learning and Teaching: The International Journal of Higher Education in the Social Sciences (LATISS); 7 (1): $12-28$.

Sow F (2002) Rethinking African Development: And What if Women Had a Say in It. General Assembly distinguished lectures, Kampala, 2002. Texts of the Cheikh Anta Diop, Claude Ake and Leopold Sedar Senghor Lectures delivered at the CODESRIA 10th General Assembly held in Kampala, Uganda in December, pp 37-51.

Underhill-Sem Y (2012) Contract scholars, friendly philanthropists and feminist activists: New development subjects in the Pacific. Third World Quarterly; 33 (6): 1095-1112.

Underhill-Sem Y, Cox E, Lacey A and Szamier M (2014) Changing market culture in the pacific: Assembling a conceptual framework from diverse knowledge and experiences. Asia Pacific Viewpoint; 55 (3): 306-318.

Woodward K and Woodward S (2015) Gender studies and interdisciplinarity. Palgrave Communications; 1, 1501810.1057/palcomms.2015.18.

\section{Additional information}

Competing interests: The author declares no competing financial interests. 
Reprints and permission information is available at http://www.palgrave-journals.com/ $\mathrm{pal} /$ authors/rights_and_permissions.html

How to cite this article: Underhill-Sem Y (2016) Critical gender studies and international development studies: interdisciplinarity, intellectual agility and inclusion. Palgrave Communications; 2:16012 doi: 10.1057/palcomms.2016.12. (c) (i) This work is licensed under a Creative Commons Attribution 4.0 cc) International License. The images or other third party material in this article are included in the article's Creative Commons license, unless indicated otherwise in the credit line; if the material is not included under the Creative Commons license, users will need to obtain permission from the license holder to reproduce the material. To view a copy of this license, visit http://creativecommons.org/licenses/by/4.0/ 